\title{
THE INTERTIDAL FAUNA OF THE MERSEY ESTUARY
}

\author{
By R. Bassindale, M.Sc. \\ Assistant Lecturer in Zoology, Manchester University
}

(Plate III)

\section{INTRODUCTION}

During a general survey of the tidal banks of the Mersey Estuary observations on the nature of the banks and on the density of the burrowing animals inhabiting them were made and were supplemented by the identification of the more common macroscopic types found.

The positions of the different areas of mud and sand were determined by means of sextant angles and plotted by station pointers. These areas are shown in Plate III and reference to them in the text is made by means of the numbers shown on the Key Chart therein.

Specimens of the common macroscopic animals inhabiting the banks were preserved in formalin for subsequent identification.

The nature of the banks (whether mud or sand) and the abundance of the infauna were ascertained from inspection of the surface layers to a depth of about one foot. All the observations were made in the summer of 1933 .

A detailed description of the topography and tidal conditions in the estuary, and the results of analyses of the water and of the material constituting the tidal banks and bed of the estuary, are given in Water Pollution Research Technical Paper, No. 7, issued by the Department of Scientific and Industrial Research (1937).

The estuary is divided into two natural divisions-the Outer Estuary or Liverpool Bay and the Upper Estuary. The Upper Estuary is that part of the estuary lying between Warrington and Rock Light. The Outer Estuary lies seaward of Rock Light and consists of a bay in which large areas of banks are exposed at low tide.

Of 37 sq. miles of tidal banks in the Outer and Upper Estuary as far as Runcorn Gap, approximately half occurs in the Outer and half in the Upper Estuary. Four-fifths (29 sq. miles) of the total area are banks of sand of which only $7 \frac{1}{2} \mathrm{sq}$. miles are inhabited (one-fifth of the total area). The remaining banks (one-fifth of the total or $7 \frac{1}{2}$ sq. miles) are of mud, and by far the greater area of mud occurs in the Upper Estuary, mainly along the Cheshire shore from Mount Manisty to the River Weaver. Densely inhabited mud is much commoner than sparsely inhabited or uninhabited mud, the former occupying approximately $6 \frac{1}{2}$ sq. miles and the two latter only i sq. mile.

The main bank of mud along the Cheshire shore is separated from the un- 
inhabited sand banks, through which the channels run by a series of patches of sparsely inhabited sand or mud, and densely inhabited sand. The main mud bank is divided into two parts by the River Gowy which, entering the Upper Estuary at Stanlow, occupies a low sandy plain flanked on either side by high mud banks.

Much of the sand is formed into waves (presumably by current action), and these areas adjoin the main channels. The island banks in the Outer Estuary have a high peak directed towards the river mouth at Rock Lighthouse, and shelve away seawards.

\section{GeNeral Description of the INFAuna}

\section{The Upper (or Inner) Estuary}

The Upper Estuary comprises the Narrows from Rock Light to Garston, a large basin extending from Garston to Runcorn and a smaller basin above Runcorn. Except at high spring tides Howley Weir (at Warrington) divides the tidal from the non-tidal reaches. Observations have not extended beyond Norton Marsh some 3 miles above Runcorn. As will be shown later in a comparison with other estuaries, this limits the collections to areas where freshwater animals are not normally found.

The most notable inhabitant of the banks is the brackish water polychaete Nereis diversicolor. This mud-living worm is found in the Upper Estuary from Norton Marsh to the Narrows wherever mud with a depth of more than a few inches occurs; it is also found in banks of mud in the Outer Estuary near the mouth of the River Alt. Large areas of the main mud bank (Areas Nos. 23 and 29, Pl. III) between Stanlow and the Weaver Sluices in the Upper Estuary are densely inhabited by this organism. At Stanlow a density of 440 per sq. m. was found from a count within a quarter metre square, and the difficulties of sieving the mud make it probable that the true figure is higher. The softer parts of the bank, in gulleys and near the Weaver Sluices, are not inhabited by Nereis. In these softer places a small red oligochaete, identified by Fraser (1932) at Dingle as Clitellio arenarius, is abundant and is the only inhabitant. In addition it usually occurs wherever Nereis is found. Both these forms appear to burrow more deeply into the mud when the surface has become dry and cracked during neap tides. Clitellio may then be found well below the surface in the form of balls containing large numbers of intertwined specimens.

At most times of the year, but particularly during the summer, the surface of the banks of mud in the Upper Estuary is covered by a green scum consisting mainly of Euglena sp., probably Euglena limosa (Fraser, 1932). The scum seems to develop most readily on the soft mud not inhabited by Nereis. Many species of diatoms are also found in the scum, and in places these are so abundant as to give the surface a dark green or brown colour. In certain areas, as on the mud-covered rocks at Runcorn Gap, Hale Head and Garston and occasionally on sand, there is a brown scum of diatoms without Euglena. Ghazzawi (1933) has identified the diatoms found on the Dingle foreshore, 
and in his list of some fifty species are to be found the names of fresh-water, marine and brackish-water species.

In addition to the scum of unicellular forms, the estuarine mud banks are frequently covered by a growth of a filamentous alga, Vaucheria sp. This alga covers the surface mud, and the tide frequently rolls up the blanket-like layer of mud and alga, and washes it away. In other parts (Area No. 33, on the foreshore near Speke) the growths appear as rounded tufts above the general level of the soft mud. Clitellio is the only recorded inhabitant of mud covered by Vaucheria.

The remaining outstanding feature of the mud banks in the Upper Estuary is the presence of the small crustacean, Corophium volutator, which builds small U-shaped burrows in the surface layers. It occurs over a large part of Areas Nos. 23 and 29 and in many other places. It is most abundant in the sandy mud of Area No. 27 near Stanlow and in the adjoining area of densely inhabited sand (Area No. 24) which contains a fair proportion of mud. It is in this neighbourhood that the small bivalve Macoma balthica is to be found, widespread and abundant in mud and muddy sand. Fraser (1932) found a maximum of 6000 Macoma per sq. m. at Dingle, and it is probable that the abundance in Areas Nos. 27 and 24 is similar or even greater than at Dingle. Macoma does not appear to tolerate soft mud nor the clayey mud of Areas Nos. 23 and 29.

The two other species of burrowing animals found commonly in the Upper Estuary are worms, and they are associated with fairly clean sand. Arenicola marina (the common lug-worm) is sparsely distributed in fairly large areas as far up as Area No. 22 on the bank between Dungeon Point and Hale Head. The tube-building form Pygospio elegans is abundant but patchy in its distribution and occurs as far up as Area No. I6.

In the Narrows at Wallasey, burrowing worms are found in greater variety than elsewhere in the Upper Estuary, seven species being recorded from Area No. 45 .

\section{The Outer Estuary (Liverpool Bay)}

The Upper Estuary opens into Liverpool Bay at the corner of a right angle formed by the Cheshire and Lancashire coasts. At low tide extensive sand banks are exposed in Liverpool Bay(Pl. III). The variety of species in the Outer Estuary is much greater than in the Upper Estuary.

Of the species occurring commonly in the Upper Estuary Nereis diversicolor has a limited distribution in mud at the mouth of the River Alt. Macoma balthica and Corophium volutator also occur near the Alt and in mud at Hoylake. Arenicola marina is much more widespread and abundant and occurs over large areas. Clitellio was not recorded. Pygospio elegans occurs near the Alt but is not widespread. Of the plants recorded from the Upper Estuary Vaucheria and Euglena were not observed in Liverpool Bay. A diatom scum occurs in places but the species were not determined. 
Two interesting low-lying areas of densely inhabited muddy sand occur on Taylor's Bank (Area No. 97) and on Spencer's Spit (Areas Nos. 60, 6I and 5I).

At Taylor's Bank the cockle, Cardium edule, occurs in abundance with a few Cardium rusticum. The burrowing heart urchin, Echinocardium cordatum, with its attendant bivalve, Montacuta ferruginosa, and the large tube-building worm, Lanice conchilega, are fairly common. In addition, the molluscs Chione striatula and Tornatella fasciata, the worms Nephthys hombergi and Arenicola marina and hydroids growing on the cockles were found. Towards the edge of the cockle bed, cockles die away and Lanice becomes more abundant finally giving way in cleaner sand to another tube-building worm, Owenia fusiformis, at Areas Nos. 98, 99 and 100. The areas of sparsely inhabited sand shown in Plate III at Area No. Ioo were actually more numerous than figured and consisted of gullies lying between the crests of long broadfronted waves of sand. At Area No. IOI, which consists of fine sand, the bivalve Donax vittatus occurs in small numbers.

The sand at Spencer's Spit has a different fauna. Donax vittatus, rare on Taylor's Bank, occurs at Area No. $6 \mathrm{I}$ in great abundance.

At Area No. 6o, Echinocardium, with Montacuta and a tube-building worm, Pectinaria koreni, are extremely abundant. Rough estimates of the abundance of these three species gave for Echinocardium (mainly up to I in. in length) I50 per sq. m. and for Donax and Pectinaria about 300 per sq. m. Other species with Donax at Area No. 6I were Echinocardium, Lanice, Arenicola and a brittle star, Ophiura texturata, which was often partly buried in the sand. At Area No. 60, with Echinocardium and Pectinaria, were Arenicola, Lanice and Donax. In the less densely inhabited sand at Area No. 62, Arenicola and Echinocardium occurred occasionally, and, near the centre of this area, Ophiura occurred in enormous numbers. Numerous patches, each about I5 sq. $\mathrm{m}$. in extent, were estimated to contain about 1600 individuals per sq. $\mathrm{m}$. Intervening areas of similar extent contained only a few specimens. Isolated specimens of six species of burrowing worms and of the razor shell, Ceratisolen legumen, were also recorded from Spencer's Spit.

The adjacent area of the shore banks (Area No. 5I) was similar to Area No. 60 and contained Lanice, Pectinaria, Owenia, Echinocardium, a few young Ensis siliqua (a razor shell), and a few Ophiura. A burrowing bivalve, the clam Mya arenaria, was common in small patches of very muddy sand.

The island banks known as the Great Burbo Bank (Areas Nos. 66-70) are composed almost entirely of coarse sand. The surface is waved and lakes occur. The North Bank is similar but does not attain the same height. It is connected to the shore banks at low water of a high spring tide. Lanice is sparsely distributed over low lying areas of fine rippled sand at Areas Nos. 63, 64, 66, 67 and 68. At Areas Nos. 63 and 64 Chione was also found, while at Area No. 65 Chione alone was found.

In 1933 along the Lancashire coast the shore banks were of fine sand with 
some mud. The sand near the Gladstone Docks contained a large amount of mud and Area No. 72 was covered by a thin layer of mud. As Formby Point was approached the sand became cleaner and only rare patches of inhabited fine sand were found at the Point. This general trend was much disturbed where the river Alt flowed across the shore. Mud inhabited by Nereis diversicolor occurred close to the channel of the Alt (Areas Nos. 79 and 80), and areas of muddy sand containing large numbers of Corophium with some Macoma (Areas Nos. 83 and 95) merged into the surrounding uninhabited clean sand.

A north-westerly gale covers the areas of mud and muddy sand near the Alt with a layer of clean blown sand and completely alters for a time the appearance of these banks. The channel of the Alt was artificially shortened in 1936, and the distribution of banks in this region has been completely altered.

In the fine muddy sand extending from Crosby to the Gladstone Dock, Arenicola marina occurred in abundance at Area No. 75 and sparsely in other areas. Macoma and a few species of burrowing worms were also found. A small gastropod, Hydrobia ulvae, occurred on the surface over most of this area of inhabited or otherwise uninhabited sand.

A patch of sand, gravel and stones overlying clay at Area No. 7I is of interest by reason of the abundance of the anemone Sagartia troglodytes in the sand. Another anemone, Tealia felina, occurred in the gravel and stones and large blue and red specimens of Nereis virens in the underlying clay. Hydroids and the barnacle Balanus crenatus were common on the stones.

The sparsely inhabited areas of sand near Formby Point contained Arenicola and Cardium with occasionally Chione and Nephthys sp.

Except near Hoylake the shore banks on the Cheshire coast are composed of cleaner and coarser sand than on the foreshore at Waterloo and they end in the East Hoyle Bank which, in the centre, attains the considerable height of $26 \mathrm{ft}$. above Liverpool Bay datum, falling away in all directions.

A low-lying bed of mussels, Mytilus edulis, on shingle and stones overlying clay occurs at Area No. 47. The large areas of sparsely inhabited sand at Areas Nos. 48 and 59 contain Cardium and Lanice; these species occur in larger numbers at Areas Nos. 49 and 50. Other species include Echinocardium, Macoma, Mactra corallina, Spisula solida, Owenia and Arenicola. The last named species is common at Area No. 50 and Owenia is common in parts of Area No. 59. Towards the tip of the East Hoyle Bank everything except Mactra corallina dies away. Lanice and Owenia reappear on the Dee side of the bank and these two species also inhabit Area No. 58. Arenicola alone occurs at Area No. 57.

At the inshore end of the East Hoyle Bank Corophium, Cardium and Macoma occur in gullies at Area No. 56. Corophium alone occurred in great abundance at Area No. 55. A reef of rock separates Areas Nos. 55 and 54. In mud at Area No. 54 Corophium lived in abundance together with Macoma, Cardium, Hydrobia and a few Arenicola. In the adjoining transitional area of 
muddy sand at Area No. 53 Macoma and Arenicola occurred in dense, alternating patches with a few Corophium. Cardium and clumps of a seaweed Enteromorpha sp. were present at the Meols end of Area No. 53 with Scoloplos armiger and Donax, which two species also occurred in the adjacent part of Area No. 52. Area No. 52, of fairly clean sand, was densely inhabited by Arenicola which died out as the cleaner and higher centre of the bank was approached.

Only a few observations were made below low-water mark; these indicated that Donax was widespread and abundant in fine sand around the tip of Taylor's Bank and that Pectinaria was abundant in sand of a more muddy character in the channels.

\section{Discussion}

An investigation of the fauna of the estuaries of the Tees and of other rivers (Water Pollution Research Technical Paper, No. 5, 1935) showed that marine animals were abundant near the mouth and became less common as the estuary was ascended until eventually no marine animals were found. Similarly, the fresh-water animals, common at the head of the estuary, were found to die out as the estuary was descended.

In order to compare different estuaries the Tees Estuary was divided into thirteen sections of equal length, and comparable sections were mapped out in other estuaries on the basis of similar salinities of the water at high and low tides.

An account of the salinity conditions in the Mersey Estuary has been published (Water Pollution Research Technical Paper, No. 7, I937, p. 3I) so that it is possible to compare points on the two estuaries which are subject to similar salinity conditions. From such a comparison it has been found that Section XIII in the Tees (from the mouth to $\mathrm{I} \frac{1}{2}$ miles above it) corresponds in the Mersey to the whole of Liverpool Bay and part of the Narrows, and that the highest point at which collections were made in the Mersey corresponds with Section $\mathrm{V}$ on the Tees. From these comparisons two points emerge.

(a) The absence of fresh-water forms from the Mersey collections (with the possible exception of fresh-water oligochaetes) is to be expected since, in the Tees and other estuaries, fresh-water animals are only represented as low as Section V by small red oligochaetes.

(b) There is no reason, on grounds of differences in salinity, why the fauna of the Narrows should not be as varied as that of Liverpool Bay. Of thirty species recorded from Liverpool Bay, however, only fifteen occur in the Narrows. It seems probable that this is due to the high speed of the tidal streams in the Narrows, the large amount of sediment in the water and the relatively small area of tidal banks.

Although the salinity in the whole of Liverpool Bay is similar to that of Section XIII in the estuary of the Tees, it seemed possible that some effect of estuarine conditions might be evident near Rock Light. Accordingly the Bay was divided by a circle with a radius of 6 miles and with the centre of the 
channel near Rock Light as its centre. Zone A (Key Map in Plate III) within the circle is subject to the discharge of the Mersey and Alt; zone B, including the East Hoyle Bank and Spencer's Spit, might be affected by the discharge of the Dee; and zone C (Formby Point and Taylor's Bank) should be least affected by any of these discharges. A list of all recorded species for each zone shows, however, that zone $\mathrm{C}$ had only fourteen species, while both A and B had twentyeight species. Any influence of the estuary which may be felt in Liverpool Bay seems therefore to have no localized adverse effect on the fauna.

Returning to a consideration of the distribution of the common burrowing animals found in the Upper Estuary it is apparent from the account given earlier in this paper that, while Nereis diversicolor (a brackish-water species) occurs above Hale Head, the common marine burrowing species only appear below Hale Head and do so one by one as the Estuary is descended from this point. This distribution is similar to the distribution of marine animals in the Tees and other estuaries.

Previous work on the fauna of the Mersey Estuary has been applied mainly to the bottom fauna of the Outer Estuary (e.g. Fraser, I935). In the Upper Estuary Fraser (1938) studied the fauna of the buoys and pontoons, and he has published a detailed account of the fauna and conditions at Dingle (Fraser, I932).

The present survey has shown that the mud banks of both the Upper and Outer Estuary are inhabited by the same species, but that the sand banks of the Outer Estuary support not only the same species as those of the Upper Estuary but in addition a large number of other species. The abundance of burrowing animals throughout the estuary is therefore due to large numbers of a few species in the Upper Estuary (notably Nereis, Macoma and Corophium) and in the Outer Estuary to a large variety of species. The fauna of the buoys and pontoons shows a similar distribution (Fraser, 1938, pp. 19, 20). The similarity of the mud-living fauna throughout must be attributed to the fact that few species can tolerate conditions in tidal mud flats, and that these few species are all tolerant of varying salinity conditions. Since it is only on parts of the coast sheltered from strong wave action that tidal mud banks can develop, and since such inlets are most liable to be subject to land drainage, it appears natural that an animal evolved to tolerate conditions on a tidal mud flat should also tolerate the conditions of salinity found in estuaries.

The lack of variety of sand-living species in the Upper Estuary when compared with the variety found in Liverpool Bay is probably due to intolerance of strong currents, varying salinity, and large amounts of suspended matter in the water.

\section{NOTES ON THE FLORA}

Large plants, whether marsh plants or marine algae, do not form an important feature of the Mersey Estuary. In the following list such observations as were made during the zoological survey of the tidal banks are given. 


\section{FLOWERING PLANTS \\ (Marsh plants or aquatic land plants)}

At one time large areas of land were flooded at high water of spring tides in the Mersey Estuary. These occurred noticeably at Wallasey, Stanlow, Frodsham, Hale Head to Runcorn, and on both sides of the river just above Runcorn. The development of Wallasey Pool as a dock area and the building of the Manchester Ship Canal led to a considerable reduction in the flood areas at Wallasey, Stanlow and Frodsham, whilst much land has been protected from flooding in the other areas. There are now limited areas subject to flooding at Frodsham Score, Hale Head to Runcorn, on each side above Runcorn, and at Norton Marsh. These areas consist of coarse grassland used for grazing sheep and are cut by drainage gullies. Other marsh plants occur spasmodically in different places, but nowhere do they occupy extensive areas. Some years ago small patches of Spartina grass were found growing on the mud at Stanlow, and to prevent their spreading and building up the mud banks, with a consequent reduction in the capacity of the estuary, the Mersey Docks and Harbour Board destroyed the plants.

Fucus vesiculosus L.

\section{ALGAE}

Growths occur on the dock walls in the Narrows and in places on each side of the river up to Hale Head and Eastham Locks. In the Outer Estuary the only notable growths occur on the Leasowe embankment and the promenades at Meols and Hoylake.

\section{Enteromorpha sp.}

Enteromorpha occurs a little higher on the walls than Fucus and has a similar distribution. In addition, tufts occur on the muddy sand at Hoylake (Area No. 53).

Porphyra sp.

A small growth occurs on the rocks at Rock Ferry and in the Manchester Ship Canal.

\section{Vaucheria sp.}

Vaucheria Thuretii Woron has been identified at Dingle (Fraser, I932), and patches - doubtless of this species-are widespread on the mud flats and near high-water mark from Dingle and Mount Manisty to Norton Marsh. Clumps and small matted growths are common on the mud at Speke (Area No. 33) and from Stanlow to the Weaver (Area No. 23).

Desmids.

Closterium sp. has been identified from below Hale Head and doubtless occurs in other localities.

\section{Euglena sp.}

The most noticeable feature of the mud banks is the presence, over extensive areas, of a bright green colour caused by immense numbers of this microscopic organism, identified at Dingle as Euglena limosa Gard (Fraser, I932). It occurs from Dingle and Eastham to Norton Marsh. 
Diatoms.

A brownish tinge in the green colour caused by Euglena is frequently observed and is due to an admixture of diatoms. Growths of diatoms, unmixed with Euglena, occur in places, mainly on sand.

Throughout the estuary the scarcity of rocky foreshores at low levels in the tidal zone prevents the extensive development of weed and the growth of numbers of species of animals associated with this type of habitat. The absence of weed from some areas of rock may be attributed to the film of mud covering them. In the case of the training walls flanking the main channels in Liverpool Bay the absence of large algae from what seems to be an admirable habitat may be due to the scouring action of the sand carried by the strong currents, although Fraser (I938, p. I6) attributes this absence to a reduction in illumination caused by the suspended matter.

\section{FAUNA LisT}

All records were made between May and October I933. Numbers refer to the Areas in the Key Map in Plate III. The names used are those of the Plymouth Marine Fauna (2nd edition) of the Marine Biological Association except where otherwise stated. Thanks are due to the Zoology Department of Liverpool University where some of the identifications were carried out.

\section{COELENTERATA}

\section{Class HYDROZOA}

Hydractinia echinata (Fleming).

Common on shells inhabited by hermit crabs, Eupagurus bernhardus. East Hoyle Bank, Spencer's Spit, Meols shore and Taylor's Bank.

Tubularia indivisa L.

Extremely abundant on the pontoons of the landing stages in the Narrows. On rocks at Gladstone Dock (7I). An average of three counts of the growth on boats moored in the Narrows gave I 300 stalks of T. indivisa per sq. in. On one boat a growth, mainly $\mathrm{I} \frac{1}{4}-\mathrm{I} \frac{1}{2}$ in. long, had grown in 16 days and was reproducing. A count showed I340 stalks per sq. in., of which 675 carried heads. Many heads had been knocked off in collecting and counting.

Laomedia gelatinosa (Pallas).

On Garston Rocks and on stones at Aigburth (36).

Aurelia aurita (L).

\section{Class SCHYPHOMEDUSAE}

During May and June I933, the Upper Estuary water carried large numbers of Aurelia aurita and many were observed in July and August. Many stranded in May and June on the sand flats from Runcorn Gap to Dungeon Point.

Tealia felina (L).

\section{Class ANTHOZOA}

Common on stones near Gladstone dock (7I). 
Sagartia elegans (Dalyell) var. venusta (Gosse).

A single specimen taken near the Gladstone Dock (7I).

Sagartia troglodytes (Price).

Abundant in gravel and sand near the Gladstone Dock (7I).

\section{ANNELIDA \\ Class CHAETOPODA \\ Order POLYCHAETA}

Lagisca extenuata (Grube).

A single specimen at Wallasey (45).

Sigalion mathildae Audouin and Milne Edwards (Fauvel, I923, p. I03).

A single specimen in sand on Spencer's Spit.

Nereis pelagica L. (45).

In sand near Gladstone Dock (73), at low-water mark at Meols (5I) and at Wallasey

Nereis diversicolor O. F. Müller.

The commonest polychaete in the Estuary. It occurs in great abundance in the Upper Estuary from below Runcorn to Rock Ferry (7, I8, 23, 29, 33, 37, 42) and sparsely from Norton Marsh to Rock Ferry (2-5, 8-15, I7, I9, 20, 24, 26, 27, 28, $34,38)$. In the Outer Estuary it is abundant in patches near the Alt (79 and 80 ) and occurs at 78 and 84 . Usually in mud, it occurs in muddy sand (never abundantly) and occasional specimens have been taken in comparatively clean sand. These, however, may have been specimens washed out of mud which burrowed as soon as they settled.

Nereis fucata Savigny.

A single specimen from Spencer's Spit.

Nereis virens Sars. (Fauvel, I923).

Burrowing in clay underlying sand and gravel near Gladstone Dock (7I) and near Leasowe with Pholas candida (near 50).

Nephthys caeca (O. F. Müller).

A single specimen in sand at Spencer's Spit.

Nephthys hombergi Lamarck.

Sparsely but widely distributed in the Outer Estuary. Specimens recorded from Meols (52), Waterloo (75), near the Alt (93), Formby (89) and Taylor's Bank (97).

Nephthys hombergi var. ehlersi Heinen (Fauvel, I923).

A single specimen from Waterloo beach in the Arenicola area (75).

Nephthys cirrosa Ehlers.

Single specimens obtained in sand from Wallasey (45), East Hoyle Sands (59) and Spencer's Spit. 
Glycera convoluta Keferstein.

A single specimen in sand from Spencer's Spit, and one in mud at the Alt (77) with spat of Macoma balthica and Cardium edule.

Scoloplos armiger (O. F. Müller).

Common in muddy sand in a small patch at Meols (53).

Nerine cirratulus (Delle Chiaje).

Taken in sand or muddy sand at Wallasey (45), Gladstone Dock (73), Spencer's Spit and East Hoyle Sands (59).

Pygospio elegans Claparède.

Very abundant in parts of the Upper Estuary in sand (I6, I7, 27 (top end near I7), $34,35,40,45)$. Outer Estuary near the Alt (77, fringes of $80,84,92)$.

Arenicola marina L.

Sparse, but widely distributed in muddy sand in the Upper Estuary (I5, I7, 22, 24, $27,30,32,35,40,44,45)$. The highest recorded specimens occurred at 15 and 22 . Abundant in the Outer Estuary at Waterloo (72-75) and at Leasowe and Hoylake (50 and 52). It occurs sparsely all over the Outer Estuary $(46,48,53,57,6 \mathrm{I}, 62,63$, $84,85,86,9 \mathrm{I}, 93,94,96,97)$ and two isolated specimens were taken on the Great Burbo Bank (69).

Owenia fusiformis Delle Chiaje.

Not taken in the Upper Estuary. Abundant in fairly clean sand in the Outer Estuary on Taylor's Bank (98, 99, I00), at Leasowe (48) and East Hoyle Sands (5 I, 58, 59).

Pectinaria koreni Malmgren.

Abundant in muddy sand on Spencer's Spit (60) and off Meols (5I) at low-water mark. Fraser (1935) records shells of P. belgica at New Brighton and quotes records of $P$. belgica from Liverpool Bay.

Lanice conchilega (Pallas).

Found only on Wallasey beach (45) in the Upper Estuary. Common and widespread in sand and muddy sand in the Outer Estuary, occurring on Taylor's Bank (97), Great Burbo Bank (66, 67, 68), North Bank $(63,64)$, Cheshire shore banks $(48,49,50,5$ I, $58,59)$ and on Spencer's Spit $(60,61,62)$. Not recorded from the Lancashire shore banks.

\section{Hydroides norvegica Gunnerus.}

Tubes were found on a dead shell on the East Hoyle Sands.

Pomatoceros triqueter (L).

Tubes found on the same shell as Hydroides norvegica.

\section{Order OLIGOCHAETA}

Clitellio arenarius O. F. Müller.

This species was identified by Fraser (1932) at Dingle (38). Small red oligochaetes occur in mud in all parts of the Upper Estuary, together with Nereis diversicolor, from Norton Marsh to Rock Ferry (2, 3, 18, 23, 29, 33, 37, 38, 42, 74). 


\section{ARTHROPODA}

\section{Class CRUSTACEA}

Sub-class COPEPODA

Eurytemora affinis (Poppe) var. hirundoides Nordquist.

Two short plankton surveys in daylight showed this species to be present at high water in the zone above Hale Head to 2 miles above Runcorn Gap. More abundant near the bottom than at the surface.

Acartia spp.

Abundant in the plankton on two surveys to just above Hale Head. Most abundant near the bottom.

\section{Sub-class CIRRIPEDIA}

Balanus crenatus Brugière.

Fairly common on stones as far as Hale Head. Common near the Gladstone Dock (7I) and on the mussels and stones at Rock Light (47). Also found on shells and stones cast up on Taylor's Bank, Spencer's Spit and the Meols shore.

Balanus balanoides (L).

Fairly common on the dock walls in the Narrows and on rocks as far as Eastham Locks. On occasional posts and rocks in the Outer Estuary.

\section{Sub-class MALACOSTRACA \\ Order ISOPODA}

Eurydice pulchra Leach.

Taken in clean sand on the Great Burbo Bank. Probably widespread in the Outer Estuary in similar situations.

Jaera marina (Fabricius).

Among weeds on the Garston Rocks.

\section{Order AMPHIPODA}

Gammarus marinus Leach.

Among weeds on the rocks at Rock Ferry (44).

Gammarus locusta (L).

In a pool near high-water mark at Crosby.

Gammarus duebeni Lilljeborg.

On the rocks at Garston and in gravel just above Garston (34). In pools at highwater mark just below Hale Head (near 20). Ship Canal near the Weaver.

Talitrus saltator (Montagu).

Local and widespread in clean sand at high-water mark. Found at Hale and Speke (I8 and 33), Mount Manisty and Hightown.

Talorchestia deshayesei (Audouin).

A single specimen taken with Talitrus saltator at Hale Head. 
Corophium volutator (Pallas)*.

Widespread and extremely abundant in muddy sand and mud with Macoma balthica and Nereis diversicolor. Also taken with Arenicola marina. Abundant at 24, 27, 42 and 44 and in parts of 23 and 29. Near high-water mark from Hale Head to Dingle $(18,33,37)$. Abundant around the Alt $(79,80,83,84$ and 95), at Hoylake (53-56) and common near the Gladstone Dock (72).

\section{Order SCHIZOPODA}

Mysids are apparently common in the Upper Estuary. Seen in abundance in shrimp nets at Garston Rocks and in a pool near Weston Locks. Taken in the plankton from Eastham to Runcorn Gap.

\section{Order DECAPODA}

Crangon vulgaris $\mathrm{L}$.

The common shrimp forms the basis of a shrimp fishery, the inner grounds being fished mainly in the Eastham to Dungeon Point region, whilst shore nets are worked at and above Garston. In the Outer Estuary the main ground is the Formby Channel and along the Crosby Channel to Rock Lighthouse. The highest point at which shrimps have been observed is near the Weaver Sluices (I2).

Eupagurus bernhardus (L).

Numerous specimens on the sand banks at Taylor's Bank, Spencer's Spit, East Hoyle Sands and Meols shore. Most of the shells carried a good growth of Hydractinia echinata.

\section{Portunus sp.}

Occasional specimens on Taylor's Bank and Spencer's Spit.

Carcinus maenas (Pennant).

Small specimens occur among rocks and gravel up to Hale Head.

Cancer pagurus L.

A specimen was taken on Taylor's Bank (97) in a pool.

Corystes cassivelaunus (Pennant).

Two females in berry were dug out of the sand near the tip of the East Hoyle Sands (59) on 20 October 1933.

\section{MOLLUSCA \\ Class PELECYPODA}

Mytilus edulis L.

The common mussel is abundant on buoys and pontoons in the river channels. On the shore it is abundant on the mussel bed at Rock Lighthouse (47) and at Wallasey (45); it has not been taken elsewhere. Fraser (1932) records it from Dingle.

\section{Montacuta ferruginosa (Montagu).}

Taken in the anal siphon of Echinocardium cordatum on Taylor's Bank (97) and Spencer's Spit (60).

\footnotetext{
* Identified at the British Museum (Nat. Hist.) by Dr I. Gordon.
} 


\section{Tellina tenuis da Costa.*}

A single young elongated specimen taken in sand near low-water mark at Leasowe (48).

Macoma balthica (L.).

The commonest bivalve of the Estuary. Found in great abundance in the mud at 27 and parts of 23 and 29. It occurs in muddy sand at 24, 26, 27 and 28 . Also found at $16,17,30,32,34,35$ and 43 . The highest recorded specimen was taken in clean sand near 10. In the Outer Estuary it occurs in abundance at the Alt $(78,79,80,84)$ and at Hoylake $(53,54,56)$, and specimens have been taken at 46, 48, 74, 75 and 94 . Spat were observed at 76 and in abundance (with spat of Cardium edule) at 77 in mud.

Donax vittatus (da Costa).

Found in extreme abundance on Spencer's Spit (6I) at low water of spring tides. It also occurs at 52,60 and Ior. On Spencer's Spit small clusters of whole and broken specimens seemed to indicate that the gulls flocking on this bank were feeding to repletion and then regurgitating. The area is exposed only at spring tides.

Mactra corallina (L.).

Found in sand near low-water mark. Large specimens were sparsely distributed over the tip of the East Hoyle Sands (59). Broken shells indicated that gulls had been feeding on them. Smaller specimens were obtained along the Meols shore (5I and 48) and as far as Leasowe.

Spisula solida (L.).

Occasional on the East Hoyle sands (59) and near Leasowe (48).

Chione striatula (da Costa).

Nowhere abundant but widely distributed in the Outer Estuary. Recorded from Taylor's Bank (97), Formby shore (87 and 88) and North Bank (63, 64, 65).

Cardium echinatum L.

Dead shell picked up on the East Hoyle Sands (59).

Cardium edule L.

Common in the Outer Estuary. Abundant on Taylor's Bank (97) and common along the Leasowe shore $(48,49,50)$ and at Hoylake $(53,54,56)$. It occurs sparsely at $71,85,86,89$ and 96 . Young specimens were abundant at 77 and 92 . In the Upper Estuary they are found at Dingle (38) where dwarfing is apparent (Fraser, 1932).

Cardium rusticum L. (Forbes \& Hanley, I853, Vol. II, p. II).

Dead shells are common along the Leasowe shore and at the Gladstone Dock. A few specimens occur on Taylor's Bank (97) among C. edule.

Mya arenaria L. (Forbes \& Hanley, I853, Vol. I, p. I68).

A large patch of small specimens occurs in mud near Stanlow (25). The species also occurs at Dingle $(37,38)$ where dwarfing is again apparent (Fraser, I932). At Rock Ferry (43) the specimens are larger than at 25 ; in localized but abundant patches of very muddy sand at $5 \mathrm{I}$ off Meols, still larger specimens occur. These last, however, are considerably smaller than the dead shells common along the Hoylake and Meols shore.

* Identified at the British Museum (Nat. Hist.) by Mr G. C. Robson. 
Mya truncata L.

A dead shell was picked up on the Meols shore (59).

Ensis siliqua (L.).

A few young specimens were dug in muddy sand off Meols (5I).

Ceratisolen legumen L. (Forbes \& Hanley, 1853, Vol. I, p. 256).

A single living specimen was taken on Spencer's Spit (60) although dead shells are common along the Leasowe shore (49).

Pholas candida L. (Forbes \& Hanley, I853, Vol. I, p. II7).

Outcrops of clay occur in the sand in many parts of the estuary. At Moreton and Leasowe several patches at about half tide level are inhabited by small specimens of Pholas candida; large dead shells are abundant along the Leasowe shore $(49,50)$ and may be picked up anywhere in the Outer Estuary.

Littorina littorea (L.).

\section{Class GASTROPODA}

The periwinkle has been found on stones at Wallasey (45), Rock Ferry (43) and at Dingle (37 and 38 ). It is extremely abundant in patches.

Hydrobia ulvae (Pennant).*

This small snail occurs on the surface of sand or mud over wide areas at the Gladstone Dock (72 and 73), Waterloo (74 and parts of 75), Hightown (84) and Hoylake (53 and 54). It also occurs in vast numbers in long pools behind the Leasowe Embankment. In the Upper Estuary it has been recorded from Dingle beach by Fraser (1932).

Natica nitida Donovan (Forbes \& Hanley, I853, Vol. III, p. 330).

Rare. Taylor's Bank (97).

Tornatella fasciata L. (Forbes \& Hanley, I853, Vol. III, p. 523).

Occasional. Taylor's Bank (97).

\section{Aeolidiidae.}

Numerous Eolids were found spawning on slag on Taylor's Bank (97) (27 Aug. 1933) and feeding on Tubularia indivisa at Gladstone Dock (71).

\section{ECHINODERMATA \\ Class OPHIUROIDEA}

Ophiura texturata Lamarck.

A few specimens were observed near low-water mark off Meols (5I). On Spencer's Spit the species was widely distributed near the centre of the bank. Numerous in patches in which the specimens formed a carpet over the surface of the sand. In an area of roughly $15 \mathrm{sq}$. yd. a count of the numbers in $\frac{1}{4} \mathrm{sq}$. $\mathrm{ft}$. indicated that there were 20,400 individuals in the patch (I400 per sq. yd.). Many similar patches occurred.

\section{Class ECHINOIDEA}

Echinocardium cordatum (Pennant).

Abundant on Taylor's Bank (97) and Spencer's Spit (60 and 6I). Less common at 62 and $5 \mathrm{I}$. Also found at 59 and 48 near low-water mark.

* Identified at the British Museum (Nat. Hist.) by Mr H. M. Tomlin. 


\section{BRYOZOA \\ Class ECTOPROCTA}

Triticella pedicillata Alder (Hincks, I880, p. 547).

Common in pools near Mount Manisty (near 32) apparently broken off from the Dolphin piles at Eastham where the growths of this species are abundant.

\section{SUMMARY}

The 37 sq. miles of intertidal banks in the Mersey Estuary have been surveyed and classified according to their nature and fauna.

Half the banks occur in the Outer and half in the Upper Estuary. Fourfifths of the total area is composed of sand and most of the remaining one-fifth of mud occurs in the Upper Estuary.

The burrowing fauna of the Outer Estuary is abundant and varied; that of the Upper Estuary is abundant but not varied.

The distribution of species in the Mersey Estuary is similar to that in the estuaries of the River Tees and Tay, except that in the Mersey Estuary a sudden drop in the numbers of species occurs at Rock Light. This is attributed to the strong tidal streams in the Narrows.

The densely inhabited banks of the Upper Estuary are mainly composed of mud and are situated high in the shore zone. In the Outer Estuary the densely inhabited banks are of muddy sand with some banks of mud and are situated near the low-water mark in sheltered positions.

The burrowing species of the Upper Estuary also occur, with many others, in the Outer Estuary.

The observations described in this paper were made during an investigation of the estuary of the River Mersey by the Water Pollution Board of the Department of Scientific and Industrial Research and the results are published by permission of the Department.

\section{REFERENCES}

Fauvel, P., I923. Polychètes Errantes. Faune de France, Vol. 5.

Forbes, E. \& Hanley, S., 1853. A History of British Mollusca and their Shells. London. Vols. I-IV.

FrASER, J. H., I932. Observations on the fauna and constituents of an estuarine mud in a polluted area. Fourn. Mar. Biol. Assoc., N.S., Vol. xviII, p. 69.

- I935. The fauna of the Liverpool Bay Shrimping Grounds and the Morecombe bay Prawning Grounds as revealed by the use of a beam trawl. Proc. Trans. Liverpool Biol. Soc., p. 65.

- I938. The fauna of fixed and floating structures in the Mersey Estuary and Liverpool Bay. Proc. Liverpool Biol. Soc., Vol. LI, pp. I-2I.

Ghazzawi, F. M., I933. The littoral diatoms of the Liverpool and Port Erin shores. fourn. Mar. Biol. Assoc., Vol. xix, p. I65.

Hincks, T., I880. British Marine Polyzoa. London.

Water Pollution Research, I935. Alexander, W. B., Southgate, B. A. and Bassindale, R. Survey of the River Tees. Part II. The Estuary-Chemical and Biological. Dept. Sci. Indus. Res., Water Pollution Research Technical Paper, No. 5. H.M. Stationery Office.

- I937. Effect of discharge of crude sewage into the estuary of the River Mersey on the amount and hardness of the deposit in the Estuary. Dept. Sci. Industr. Res., Water Pollution Research Technical Paper, No. 7. H.M. Stationery Office. 

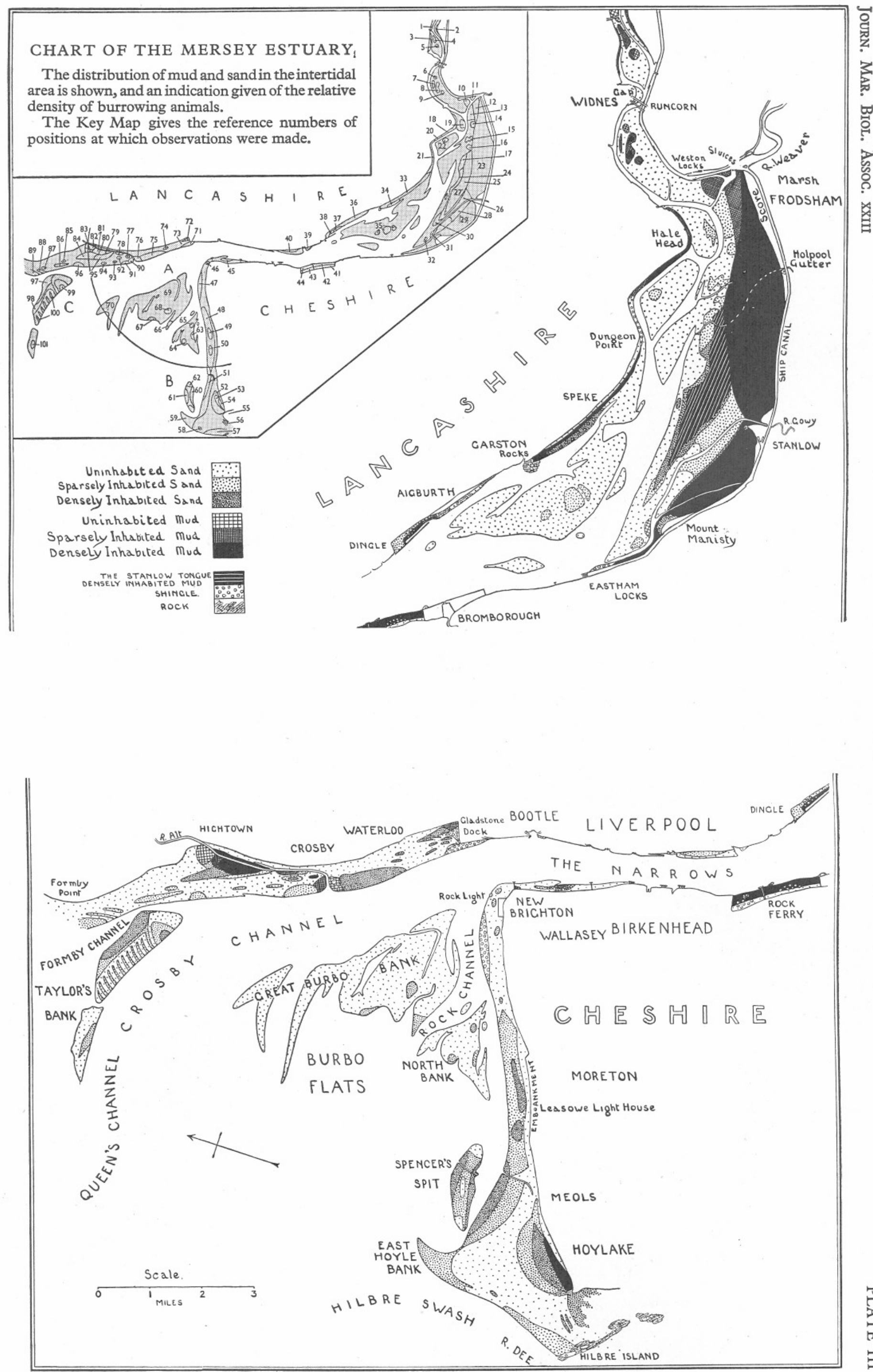